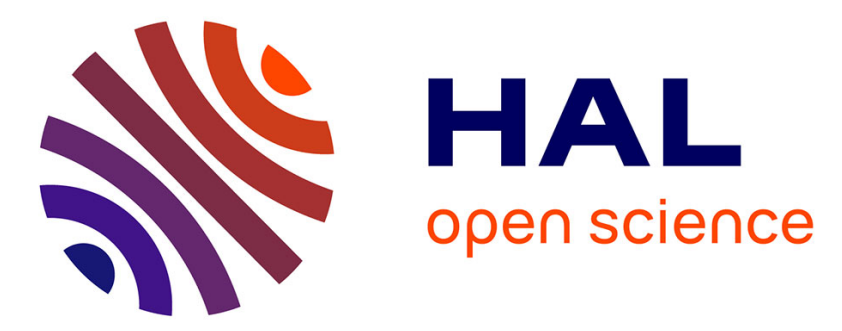

\title{
Immunological cross-reaction between pituitary gonadotropin from North Atlantic fish
}

V.J. Bye, Bernard Breton, Roland Billard

\section{To cite this version:}

V.J. Bye, Bernard Breton, Roland Billard. Immunological cross-reaction between pituitary gonadotropin from North Atlantic fish. General and Comparative Endocrinology, 1980, 41 (1), pp.130134. 10.1016/0016-6480(80)90042-8 . hal-01601678

\section{HAL Id: hal-01601678 \\ https://hal.science/hal-01601678}

Submitted on 2 Jun 2020

HAL is a multi-disciplinary open access archive for the deposit and dissemination of scientific research documents, whether they are published or not. The documents may come from teaching and research institutions in France or abroad, or from public or private research centers.
L'archive ouverte pluridisciplinaire HAL, est destinée au dépôt et à la diffusion de documents scientifiques de niveau recherche, publiés ou non, émanant des établissements d'enseignement et de recherche français ou étrangers, des laboratoires publics ou privés.

\section{다(1)(2)}

Distributed under a Creative Commons Attribution - ShareAlikel 4.0 International 


\title{
Immunological Cross-Reaction between Pituitary Gonadotropin from North Atlantic Fish
}

\author{
V. J. Bye, ${ }^{*}$ B. Breton, $\dagger$ AND R. Billard $\dagger$ \\ *Ministry of Agriculture, Fisheries and Food, Fisheries Laboratory, Lowestoft, Suffolk, England, and \\ $\dagger$ Institut National de la Recherche Agronomique, Laboratoire de Physiologie des Poissons, \\ 78350 Jouy-en-Josas, France
}

Accepted December 6, 1979

\begin{abstract}
Pituitary extracts of 14 species of fish from the North Atlantic were tested in rainbow trout and carp gonadotropin radioimmunoassays (RIA). The poor cross-reaction and low gonadotropin content measured in the pituitary extracts indicate that RIA used for trout and carp gonadotropins are unsuitable for these species. The degree of specificity in the two systems does not reflect the phylogenetic relationships of the tested species. It is suggested that fish gonadotropins are species specific so that a sensitive RIA must be developed for each family investigated.

A species specificity between fish and mammalian gonadotropins was suggested by work on goldfish spermatogenesis (Billard et al., 1970; Billard and Escaffre, 1973). Specificity among some groups of freshwater fish has also been indicated by other work on gonadotropins (Burzawa-Gérard and Fontaine, 1972; Fontaine et al., 1972; Breton et al., 1973). However during the final stages of gametogenesis (ovulation and spermiation) the species specificity appears to be less pronounced since human chorionic gonadotropin or heterologous pituitary preparations are potent treatments (cf. reviews by Pickford and Atz, 1957; Barnabé and René, 1972; Kuo et al., 1973; Shehadeh et al., 1973; De Vlaming, 1974).

In the present study the immunological cross-reaction between pituitary preparations of a variety of fish species was tested in order to extend the investigation of species specificity and to examine the possibility of gonadotropin measurement in other species using carp and trout radioimmunoassay (RIA) systems already available (Breton et al., 1971; Breton and Billard, 1977).
\end{abstract}

\section{MATERIALS AND METHODS}

Preparation of the pituitary. Pituitaries were collected in March 1973 during a cruise aboard the MAFF Research Vessel CIROLANA in the North Sea and Barents Sea from both sexes of the species listed in Table 1.

Pituitaries were collected from freshly caught fish, immediately plunged into cold acetone $\left(-10^{\circ}\right)$, and then homogenized in the same medium. The pituitary material was dried and then homogenized in a glassTeflon homogenizer at $5 \mathrm{mg} \mathrm{ml}^{-1}$ in $0.025 \mathrm{M}$ veronal buffer $\mathrm{pH} 8.6$, containing $2.5 \%$ human serum albumin. Extraction was allowed to proceed overnight at $4^{\circ}$ with gentle stirring. The mixture was then centrifuged at $5000 \mathrm{~g}$ at $4^{\circ}$ for $20 \mathrm{~min}$. Dilution of the supernatant gave the following set of concentrations: $1,0.75,0.25$, $0.075,0.05$, and $0.025 \mathrm{mg}$ of acetonic powder $\mathrm{ml}^{-1}$.

RIA systems. All the pituitary extracts were tested by competition in the two RIA systems using purified fish gonadotropins.

The carp system was used in the conditions previously reported (Breton et al., 1973).

The trout system used a gonadotropin purified from rainbow trout (t-GTH) (Breton et al., 1976) and an antiserum prepared in guinea pig against the salmon gonadotropin $\mathrm{S}_{\mathrm{G}}-\mathrm{G} 100$ (Donaldson et al., 1972). The initial concentration of the antibody was 1 to 30,000 . t-GTH was iodinated ( ${ }^{125}$ I Radiochemical Centre, Amersham, England) by the method described by Greenwood et al. (1963). Incubation and competition were as described for the carp system (Breton et al., 1971).

Presentation of the results in Tables 2 and 3. Results for each immunological cross-reaction are expressed by the relationship logit $B / B_{0}=f(\log$ dose). The slope of the curve, the coefficient $R$ for the linearity, and the t-GTH or c-GTH equivalent were also calculated for each species. Regression curves were compared by considering their residual variances (dispersion around the regression line), slopes, and zero intercepts according to the Snedecor and Cochran (1967) method.

\section{RESULTS}

In Tables 2 and 3 the species are classified according to the parallelism between 
TABLE 1

\begin{tabular}{|c|c|c|c|}
\hline Order & Family & Species & \\
\hline \multicolumn{4}{|l|}{ Teleosts } \\
\hline \multirow[t]{4}{*}{ Heterosomata } & Pleuronectidae & Plaice & Pleuronectes platessa \\
\hline & & Dab & Limanda limanda \\
\hline & & Long rough dab & Hippoglossoides platessoides \\
\hline & & Halibut & Hippoglossus hippoglossus \\
\hline \multirow[t]{3}{*}{ Anacanthini } & Macrouridae & Grenadier & Coryphaenoides rupestris \\
\hline & Gadidae & Cod & Gadus morhua \\
\hline & & Haddock & Melanogrammus aeglefinus \\
\hline \multirow[t]{3}{*}{ Isospondyli } & Osmeridae & Smelt & Osmerus eperlanus \\
\hline & & Capelin & Mallotus villosus \\
\hline & Clupeidae & Herring & Clupea harengus \\
\hline \multirow[t]{2}{*}{ Scleroparei } & Scorpaenidae & Redfish & Sebastes marinus marinus \\
\hline & Cyclopteridae & Lumpsucker & Cyclopterus lumpus \\
\hline Percomorphi & Anarhichadae & Catfish & Anarhichas minor \\
\hline \multicolumn{4}{|l|}{ Elasmobranchs } \\
\hline Selachii & Rajidae & Starry ray & Raja radiata \\
\hline
\end{tabular}

the slope of their competitive inhibition curve and those obtained with the specific hormone used in each system. The slope varied from -0.87 to -0.20 with the trout system and from -1.37 to -0.18 with the carp system. There were no significant differences between the coefficients of linearity for the various inhibition curves.
The immunological specificity was rarely the same in the two systems. Grenadier, cod, and lumpsucker showed marked differences. However the specificity of smelt and ray was particularly low in both systems.

The degree of specificity in the systems did not closely reflect the phylogenetic re-

TABLE 2

Trout RIA SySTEM

\begin{tabular}{lccc}
\hline $\begin{array}{c}\text { Alkaline } \\
\text { pituitary } \\
\text { extract from }\end{array}$ & $\begin{array}{c}\text { Coefficient of } \\
\text { correlation } R\end{array}$ & $\begin{array}{c}\text { Slope of the curve logit } \\
\left(B / B_{0}\right)=f(\text { log dose })\end{array}$ & $\begin{array}{c}\text { Equivalent } \\
\text { t-GTH ng } \mathrm{mg}^{-1}\end{array}$ \\
\hline Pure t-GTH & -0.998 & -0.925 & 5954.0 \\
+ immature & -0.995 & -0.915 & 66880.0 \\
$\quad$ rainbow trout & & & 0.8 \\
\& mature & -0.995 & -0.886 & 210.9 \\
$\quad$ rainbow trout & -0.989 & & 3.0 \\
Cod & -0.998 & -0.869 & 9.6 \\
Halibut & -0.978 & -0.774 & 5.6 \\
Plaice & -0.998 & -0.716 & 2.5 \\
Herring & -1.057 & -0.714 & 6.9 \\
Haddock & -0.992 & -0.662 & 8.7 \\
Redfish & -0.994 & -0.648 & 2.6 \\
Catfish & -0.954 & -0.585 & 2.9 \\
Dab & -0.993 & -0.586 & 17.6 \\
Long rough dab & -0.981 & -0.536 & 2.1 \\
Capelin & -0.987 & -0.463 & 4.9 \\
Starry ray & -0.979 & -0.434 & 1.0 \\
Smelt & -0.899 & -0.316 & -0.292 \\
Grenadier & -0.913 & -0.197 & \\
\hline
\end{tabular}


TABLE 3

CARP RIA SYSTEM

\begin{tabular}{lccc}
\hline $\begin{array}{l}\text { Alkaline } \\
\text { pituitary } \\
\text { extract from }\end{array}$ & $\begin{array}{c}\text { Coefficient of } \\
\text { correlation } R\end{array}$ & $\begin{array}{c}\text { Slope of the curve logit } \\
\left(B / B_{0}\right)=f(\log \text { dose })\end{array}$ & $\begin{array}{c}\text { Equivalent } \\
\text { c-GTH ng } \text { m }^{-1}\end{array}$ \\
\hline Pure c-GTH & -0.995 & -0.973 & \\
Carp & -0.992 & -0.969 & 14200.0 \\
Grenadier & -0.974 & -1.374 & 3.6 \\
Dab & -0.960 & -1.156 & 1.2 \\
Plaice & -0.974 & -1.002 & 5.0 \\
Herring & -0.984 & -1.000 & 1.1 \\
Long rough & -0.997 & -0.965 & 1.6 \\
dab & -0.996 & -0.931 & 2.0 \\
Halibut & -0.905 & -0.896 & 0.5 \\
Haddock & -0.996 & -0.790 & 2.6 \\
Capelin & -0.974 & -0.721 & 3.2 \\
Redfish & -0.807 & -0.659 & 1.2 \\
Cod & -0.985 & -0.654 & 2.3 \\
Catfish & -0.995 & -0.618 & 2.8 \\
Lumpsucker & -0.924 & -0.461 & 4.0 \\
Starry ray & -0.961 & -0.183 & 2.5 \\
Smelt & & & \\
\hline
\end{tabular}

lationships of the tested species. For example, although the pleuronectids were grouped in the carp system they were in two separated groups in the trout system. The osmerids were closer when tested against trout than against carp. The gadids were not grouped in either system.

Although the herring, smelt, and capelin are in the same order as the trout their phylogenetic relationship is not more apparent in the trout system than it is in the carp system.

Pituitary contents expressed in equivalents of c-GTH and t-GTH were very low in all the species tested in comparison with the homologous extracts. The trout system seems to be less specific than the carp but more sensitive. The high t-GTH equivalent for the lumpsucker in the trout system is not easily explained.

\section{DISCUSSION}

The high immunological species specificity for pituitary gonadotropins shown in this study indicates that a RIA to measure pituitary and plasma gonadotropin content using a carp or trout system is not suitable for the species tested.
Similar results have been obtained by Tan and Dodd (1978) using a heterologous RIA incorporating anti-salmon GTH and carp GTH as standards. In their system specificity was enhanced for some of the species examined, but there was no indication of the sensitivity of the assay.

Our results have been obtained from total pituitary extracts in which other components are able to destroy the immunoreactivity of the GTH. This was clearly demonstrated for growth hormone by Hayashida et al. (1975) and Farner et al. (1976). Crude pituitary extracts from nonmammalian species show varying degrees of nonparallelism with rat GH standard, but purified $\mathrm{GH}$ from the same species exhibits steeper curves which may be completely parallel. However, the experiments of Tan and Dodd (1978), and Breton and BurzawaGerard (1972), using crude pituitary extracts, in which parallelism with salmon and carp GTH standards was shown only for species within the respective family argues against this hypothesis.

Alternatively, the presence of proteolytic enzymes in the crude pituitary extracts or the reproductive condition of the donors 
might account for the low values of pituitary GTH in our assays. In trout the pituitary content of GTH is 11 times greater in mature females than in immature fish (Table 2). However, the majority of the fish sampled were mature and either spawning or just spent and it is known for some species (trout, carp, and tench) that pituitary GTH content is still high in the spent condition (Breton et al., 1976). It is more probable that the low values result from the high specificity of the antibodies employed, which cross-react well only with the antigens to which they have been raised.

The pronounced species specificity in the immunoreactive activity of gonadotropin throws doubt on the validity of RIA using a homologoús system which differs from the GTH under assay. Although an immunological cross-reaction of $10 \%$ gives a positive reaction by immunofluorescence with antisera against o-LH and c-GTH in some species (Billard et al., 1971; Goos et al., 1976), it does not give specific displacement curves in a carp RIA system (Breton et al., 1973) and it cannot be used for RIA, contrary to the suggestion of Goos et al. (1976).

It appears that some of the pituitary powders tested contained some common antigenic determinants. However these do not appear to be closely related to the phylogeny of the donor species. These common sites could be sufficient for a positive reaction in immunofluorescent studies, but not adequate for quantitative measurements. To provide a sensitive RIA system it will be necessary to obtain gonadotropin of at least each family, and probably of each genus, under investigation. These results confirm that the GTH of each fish species has a unique structure as has been demonstrated in other classes of vertebrates.

\section{ACKNOWLEDGMENTS}

This work was partially supported by a CNEXO grant. Pierette Reinaud provided valuable technical assistance and Dr. C. Campbell read and commented on the manuscript.

\section{REFERENCES}

Barnabé, G., and René, F. (1972). Reproduction controlée du Loup Dicentrarchus labrax (Linné) et production en masse d'alevins. C.R. Acad. Sci. Paris 275, 2741-2744.

Billard, R., and Escaffre, A. M. (1973). Effects of HCG and gonadotropin on the maintenance of spermatogenesis in hypophysectomised goldfish (Carassius auratus). International Research Communications System, (73-12), 15-1-20.

Billard, R., Burzawa-Gerard, E., and Breton, B. (1970). Régénération de la spermatogénèse du Cyprin hypophysectomisé Carassius auratus $\mathrm{L}$. par un facteur gonadotrope hautement purifie de Carpe. C.R. Acad. Sci. Paris 271, 1896-1899.

Billard, R., Breton, B., and Dubois, M. P. (1971). Immunocytologie et histochimie des cellules gonadotropes et thyréotropes hypophysaires chez la Carpe Cyprinus carpio. C.R. Acad. Sci. Paris 272, 981-983.

Breton, B., and Billard, R. (1977). Effects of photoperiod and temperature on plasma gonadotropin and spermatogenesis in the rainbow Trout salmo gairdneri. Richardson. Ann. Biol. anim. Biochim. Biophys. 17, 331-340.

Breton, B., and Burzawa-Gerard, E. (1972). Etude de la. spécificité immunologique des hormones gonadotropes de poissons par radioimmunologie. Colloque INSERM PARIS, Mai 1972. Les hormones glycoprotéiques. 223-232.

Breton, B., Kann, G., Burzawa-Gerard, E., and Billard, R. (1971). Dosage radioimmunogique d'une hormone gonadotrope de Carpe Cyprinus carpio L. C.R. Acad. Sci. Paris 272, 1515-1517.

Breton, B., Billard, R., and Jalabert, B. (1973). Spécificité d'action et relations immunologiques des hormones gonadotropes de quelques Téléostéens. Ann. Biol. anim. Biochim. Biophys. 13, 347-362.

Breton, B., Jalabert, B., and Reinaud, P. (1976). Purification of gonadotropin from rainbow Trout pituitary. Ann. Biol. anim. Biochim. Biophys. 16, 25-36.

Burzawa-Gerard, E., and Fontaine, Y. A. (1972). The gonadotropins of lower vertebrates. Gen. Comp. Endocrinol. 3, 715-718.

De Vlaming, V. L. (1974). Environmental and endocrine control of teleost reproduction $\ln$ "Control of Sex in Fishes"' (C. B. Schreck, ed.), pp. 13-83: Virginia Polytechnic Institute and State University, Virginia.

Donaldson, E. M., Yamazaki, F., Dye, H., and Philleo, W. W. (1972). Preparation of gonadotropin from salmon (Oncorhynchus tshawytscha) pituitary glands. Gen. Comp. Endocrinol. 18, $469-481$. 
Farner, S. N., Papkoff, H., and Hayashida, T. (1976). Purification and properties of reptilian and amphibian growth hormone. Endocrinology 99, $692-700$.

Fontaine, Y. A., Salmon, C., Fontaine-Bertrand, E., Burzawa-Gerard, E., and Donaldson, E. M. (1972). Comparison of the activities of two purified fish gonadotropins on adenyl cyclase activity in the goldfish ovary. Canad. J. Zool. 50, 1673-1676.

Greenwood, F. C., Hunter, W. H., and Glover, J. S. (1963). The preparation of $I^{131}$ labelled human growth hormone of high specific radioactivity. Biochem. J. 89, 114-123.

Goos, H. J. Th., Seldenrijk, R., and Peute, J. (1976). The gonadotropic cells in the pituitary of the black molly Mollienisia latipinna and other teleosts identified by the immunofluorescent technique in normal and androgen treated animals. Cell. Tiss. Res. 167, 211-219.

Hayashida, T., Farner, S. N., and Papkoff, H. (1975). Pituitary growth hormones: Further evidence for evolutionnary conservation based on immunochemical studies. Proc. Nat. Acad. Sci. U.S.A. 72, 4322-4326.

Kuo, C. M., Shehadeh, Z. H., and Nash, C. E. (1973). Induced spawning of captive grey Mullet (Mugil cephalus $L$.) females by injection of human chorionic gonadotropin (HCG). Aquaculture 1, $429-432$.

Pickford, G. E., and Atz, J. W. (1957). "The Physiology of the Pituitary Gland of Fishes." New York Zoological Society.

Shehadeh, Z. H., Küo, C. M., and Milisen, K. K. (1973). Induced spawning of grey Mullet (Mugil cephalus $L$ ) with fractionated salmon pituitary extract. J. Fish. Biol. 5, 471-478.

Snedecor, G. W., and Cochran, W. G. (1967). "Statistical Methods," 6th ed. Iowa State University Press, Ames, Iowa.

Tan, E. S. P., and Dodd, J. M. (1978). Immunological relatedness of gonadotropins of various fishes as shown by radioimmunnassay. Ann. Biol. Anim. Biochim. Biophys. 18, 781-785. 